\title{
The occurrence and history of Tetragonia decumbens (Aizoaceae) in New South Wales
}

\author{
Petrus C. Heyligers
}

\begin{abstract}
Heyligers, P.C. (CSIRO Wildlife and Ecology, GPO Box 284, Canberra, ACT 2601, Australia) 1999. The occurrence and history of Tetragonia decumbens (Aizoaceae) in New South Wales. Telopea 8(3): 371-373. The correct name for this uncommon, introduced strand plant in New South Wales is shown to be Tetragonia decumbens Mill. rather than T. nigrescens Eckl. \& Zeyh. The history of the usage of the incorrect name is investigated and the past and present distribution of this species in New South Wales discussed.
\end{abstract}

\section{Introduction}

In March 1993, at the harbour entrance to Newcastle, I found a plant I knew well from the dunes in south-western Western Australia: Tetragonia decumbens Miller, African Spinach. This species is native to the shores of southern Africa (Adamson 1955, Lubke et al. 1997) and in Western Australia was first collected in 1932 near Cottesloe, a seaside suburb of Perth. It has winged, corky fruits and, like those of its congener T. tetragonioides (Pallas) Kuntze, New Zealand Spinach, these fruits are buoyant in seawater. However, T. decumbens is not mentioned in the Flora of New South Wales (Jacobs \& Highett 1990) and because the flowers are pedicellate, the Newcastle plant keys out to T. nigrescens Eckl. \& Zeyh. As it was not a '[s]oft, prostrate, slightly succulent, green or purplish herb with underground tuber,' but a suffrutescent decumbent plant with thick, succulent, saddle-shaped leaves, it was obviously a different species. In this paper I report on the incorrect identification and describe the past and present distribution of T. decumbens in New South Wales.

Nomenclature follows the various authors, as referred to in the text; the spelling of T. tetragonioides is adopted from Gray (1997).

\section{The identity of Tetragonia nigrescens from New South Wales}

The name used in the Flora of New South Wales dates back to a misidentification of a plant found in 1916. Inspection of the collections at NSW, SYD and UNSW show that this and other New South Wales specimens kept under T. nigrescens var. maritima Sond. are in fact T. decumbens. From annotations on the folder at NSW it was apparent that Jacobs had already questioned this identification during the preparation of the 'Flora of New South Wales'. Consulting the most recent monograph on the South African species in this genus (Adamson 1955) left me in no doubt about the correct name for these specimens. His key leads to the series Decumbentes, which is characterized by stems, woody at the base, and rather rigid, papillose wings on the ripe fruit. In this series of three species T. decumbens is the only one that is decumbent. Adamson (1955) and Friedrich (1967) point out that this taxon is very variable in size, in woodiness of the stems, and in leaf shape and succulence. For this reason Adamson does not maintain the varieties listed by Fenzl (1862) and includes T. zeyheri Fenzl, the name in use for the Western Australian plants, in T. decumbens as well, as it 'is merely a form 
from rather dry habitat.' Friedrich (1967) considers the other two taxa in the Decumbentes to be conspecific with T. decumbens as well. Ms P. Burgoyne at the National Herbarium in Pretoria (PRE) has subsequently confirmed the correctness of this re-identification. Prescott (1984) and Rye (1987) provide good descriptions of this taxon.

\section{Use of the name Tetragonia nigrescens}

As far as I am aware, the floras of Beadle et al. (1962) and Beadle (1972) were the first in which T. nigrescens var. maritima was documented. The description of this taxon fits the plants found in New South Wales reasonably well; in other words, it appears to be based on knowledge of live specimens (Evans had collected the species at Maroubra, see below). In contrast, the diagnosis in the Flora of New South Wales (Jacobs \& Highett 1990), like that in the Flora of Australia (Prescott 1984), is closely paraphrased from Adamson (1955) and hence the name of the variety was dropped as Adamson, as for T. decumbens, had found that the varieties recognized by Fenzl (1862) could not be upheld.

\section{Past and present distribution of T. decumbens in New South Wales}

The first collection of T. decumbens in New South Wales was made by A.A. Hamilton on 11 November 1916 at Maroubra Bay, Sydney (Hamilton s.n., NSW 429307, 429308) and exhibited at the May 30, 1917 meeting of the Linnean Society of New South Wales (Anon. 1917). In February 1919 T. decumbens was also found at Camp Cove near South Head, at the entrance to Sydney Harbour (Bryant s.n., NSW 429309). At Maroubra it was collected again in 1933 (Radford s.n., NSW 429310) and in 1955 (Evans s.n., SYD). As a search in 1998 revealed, T. decumbens has disappeared from both locations.

In the 1940s Mort (1949) made an extensive survey of the dune flora of New South Wales with a view to selecting species suitable for dune rehabilitation. On 1 August 1947 he collected T. decumbens at Stockton Beach (Mort s.n., NSW 3939). Being at the harbour entrance to Newcastle, this location is rich in ballast plants, including several introduced from South Africa, for example Cotula turbinata and Ursinia chrysanthemoides (Asteraceae) and Hebenstretia dentata (Selaginaceae) (pers. obs.), and Trachyandra divaricata (Asphodelaceae; Heyligers in press). T. decumbens has persisted in the area (e.g. Lower Hunter River, Winning s.n., 8 Feb1988 (NSW 216083); Newcastle Head, Heyligers 93016, 2 Aug 1993 (CANB, NSW); Stockton, Heyligers 98006, 29 Oct 1998 (CANB)).

In 1993 T. decumbens was also collected near Birubi Point, Anna Bay, about 25 km northeast of Stockton (Coveny 16487, NSW), where it was still present in 1998. Its occurrence in this area is most likely due to an accidental introduction during dune restoration work. There are no other documented occurrences from New South Wales, and although T. decumbens may be present in a few other locations (P.J. Clarke, pers. comm.), it is clear that, in contrast to Western Australia, its distribution in New South Wales has remained quite sporadic.

\section{Acknowledgments}

It is a pleasure to thank Heads, Curators and other staff from the Australian National Herbarium (CANB), the National Herbarium of New South Wales (NSW) and the following university herbaria: University of New England (NE), University of Sydney (SYD) and the University of New South Wales (UNSW) for their co-operation. I am grateful to Dr B. Walker, Chief of CSIRO Wildlife and Ecology, for having me as an 
Honorary Fellow in his Division and to Mr D. Benson (NSW), Dr P.J. Clarke (University of New England), Dr S.W.L. Jacobs (NSW), Dr R.F. Parsons (LaTrobe University), Dr P. Wilson (NSW) and an anonymous reviewer for their comments on the draft. I am also indebted to Dr P. Wilson and Ms M. Jordaan for having the reidentification of T. nigrescens checked by Ms P. Burgoyne at the National Herbarium in Pretoria (PRE).

\section{References}

Adamson, R.S. (1955) The South African species of Aizoaceae. II. Tetragonia. J. S. African Bot. 21: 109-149.

Anonymous (1917) Ordinary Monthly Meeting May 30th, 1917: Notes and Exhibits. Proc. Linn. Soc. New South Wales 42: 247.

Beadle, N.C.W., Evans, O.D. \& Carolin, R.C. (1962) Handbook of the Vascular Flora of the Sydney District. (The authors: Armidale).

Beadle, N.C.W. (1972) Students Flora of North Eastern New South Wales, part II. (University of New England: Armidale).

Fenzl, E. (1862) Tetragonia. Pp 460-469 in Harvey, W.H. \& Sonder, O.W. (eds) Flora Capensis, vol. II. (Hodge, Smith \& Co.: Dublin).

Friedrich, H.-Ch. (1967) Tetragoniaceae. Pp. 28:1-28:7 in Merxmüller, H. (ed.) Prodromus einer Flora von Südwestafrica, Lieferung 10. (J. Cramer: Lehre).

Gray, M. (1997) A new species of Tetragonia (Aizoaceae) from arid Australia. Telopea 7: 119-127.

Heyligers (in press) Dispersal of the exotic coastal dune plants Gladiolus gueinzii and Trachyandra divaricata in Australia. Cunninghamia 6(2).

Jacobs, S.W.L. \& Highett, J. (1990) Aizoaceae. Pp. 188-199 in Harden, G. (ed.) Flora of New South Wales, vol. 1. (New South Wales University Press: Kensington).

Lubke, R.A., Davis, A.M., Steinke, T.D. \& Boucher, C. (1997) Coastal Vegetation. Pp. 300-321 in Cowling, R.M., Richardson, D.M. \& Pierce, S.M. (eds) Vegetation of Southern Africa. (Cambridge University Press: Cambridge).

Mort, G.W. (1949) Vegetation survey of the marine sand drifts of New South Wales. J. Soil Conservation Service New South Wales 5: 84-91.

Prescott, A. (1984) Tetragonia. Pp. 37-41 in George, A.S. (ed.) Flora of Australia, vol. 4.

Rye, B.L. (1987) Aizoaceae. Pp 76-80 in Marchant, N.G., Wheeler, J.R., Rye, B.L., Bennett, E.M., Lander, N.S. \& Macfarlane, T.D. (eds) Flora of the Perth Region. (Western Australian Herbarium, Department of Agriculture: Western Australia). 
